\title{
The problem occurred in students' writing when using Picture Series technique in learning recount text
}

\author{
Firanda Dias Indah Fitrian ${ }^{1}$, Sudirman Sudirman ${ }^{2}$, Dian Shafwati ${ }^{3}$ \\ English Education Department, Faculty of Teacher Training and Education ${ }^{123}$ \\ Bandarlampung, Lampung, Indonesia ${ }^{123}$ \\ e-mail: fira.nda@yahoo.com ${ }^{1}$; sudirman@yahoo.com² \\ dianshafwati@fkip.unila.ac.id ${ }^{3}$
}

\begin{abstract}
The aim of this study was to find out the problem occurred in students' writing when using picture series technique in learning recount text. This research was a qualitative research. The subjects of this research were 36 students of SMAN 10 Bandar Lampung in academic year $2019 / 2020$ at the second semester. Interview, analyzing students' worksheets and observation sheet were the instrument that used to collect the data. Before taking the data, the students had already been taught by picture series technique as a treatment. Furthermore, there is statistically significant improvement of students' writing achievement on recount text written by the students after they were taught through picture series technique. After that, interview was done, as one of the instrument, in order to find out the result of this research. The result shows that one of the most common problems is the students still confused with the use of past tense and past continuous tense and lack of vocabulary on the students' worksheets. Based on the analysis of the students worksheets it was found that some of the students still use English-Indonesian language. In addition, it was found that the problems that the students made in their writing recount text worksheets are classified into four aspect of writing, namely organization, content, grammar, and vocabulary.
\end{abstract}

Keywords: writing, problem, recount text, picture series technique.

\section{INTRODUCTION}

Writing is a complex process of innovation as it involves idea generating, grammar, vocabulary mastery, and the art of organizing the ideas cohesively (Firmansyah, 2015). English has its own grammatical system that is different from Indonesian. For example, when the students want to tell their past experiences in English, they have to pay attention to the use of past tense. In fact, the students do not have to consider the tenses because there are no tenses in Indonesian. Moreover, English is not their mother tongue. It is difficult for them to construct sentences. They also have difficulties to construct sentences into well-organized pharagraph. They often insert Indonesian words while writing English texts. They usually become confused and lose their ideas in the midst of their writing.

Developing clear and accurate expression through writing presents major problems for most students with learning difficulties. Sturm and Koppenhaver in Westwood (2008:57) told us that the composing for writing involves complex thinking that must integrate multiple components including the topic of the theme, choice of words, organization, purpose, audience clarity, sequence cohesion, and transcription. From that statement, we know that writing is complicated activity which the competence in writing in different purposes relies heavily on possession of 
adequate vocabulary, knowledge of syntactical structure, and appropriate strategies for planning, composing, reviewing and revising written language which the problems can arise for some students.

According to Westwood (2008: 60-62), there are some areas encountered by the students when they are ordered to write a text. The main problems appear in at least four areas. They are problems in content, process approach, mechanics, and spelling. The first problem is content. Weak writer produce a much smaller amount of work than a proficient writer. It means that the students have difficulty in expressing their idea in written form or producing longer written test. Hess and Wheldall in Westwood (2008: 61) said that weak writers spend little or no time thinking and planning before they start to write. It means that lack of planning is one of the reasons why some students write very little, and why their ideas are not pretended in logical order. The second is process approach. Weak writers usually reluctant to review, edit, and polish a first draft.

Wojosinski and Smith in Westwood (2008:61) acknowledge that students with learning difficulties are often resistant to going through the stages of process writing preferring instead to write quickly to get the job done. Graves in Westwood (2008:61) said that process approach to writing helps young writers understand that a first attempt in writing rarely produces a highquality finished product. It can be concluded that process approach is very important in writing but some students do not aware about that so it makes their writing are poor.

The third is mechanics. Weaker writer tend to be preoccupied with the mechanical aspects of writing. According to Graham and Harris in Westwood (2008: 62) said that mechanics has been identified as one of the mean characteristics of students with a specific learning disability in writing; it is also a common problem with almost all weak writers too. He also stated that it is reported that 23 percent of students have significant difficulties with handwriting and that poor handwriting and spelling interfere with the composition process by draining too much cognitive effort away from the creative and expressive component. The last main problem is spelling. Weaker writer have a problem with spelling. Learning to spell in a language like English is not an easy task, and many students have difficulties generating the correct spelling of the words. They invent to use in their writing.

One of the media that can be used to improve the students' writing skills is pictures series. According to Lindstormberg (2004), by using picture series, the students will be interested and will enjoy the teaching and learning process. The pictures lead the students to focus directly on words. It is in line with Le's statement (2005) that the use of picture series gives positive effects such as motivation, enthusiasm, understanding about ideas generation, inependence in constructing sentences, high sentence production and cooperative learning. However, new technique also is not perfect. There are also some problems in students' writing occurred after using this technique. Within this context, this research seeks to investigate the problem occurred in students' writing when using picture series technique in learning recount text. 


\section{METHODS}

This research adopts a qualitative approach. The objectives of this research were to find The problem occurred in students' writing when using picture series technique in learning recount text. The subjects of this research were 36 students of 10 MIA 2 in SMAN 10 Bandar Lampung in academic year 2019/2020 at the second semester. The data are collected by using observation sheet, analyze students' worksheets and interview. Observation was carried out during the treatment by paying attention to the problems that occurred when the treatment was given. The researcher as the interviewer asked one question to some students about the obstacle during the treatment. The question was given on the last day. Further, the data of the observation, interview, and students' worksheet were interpreted in order to answer the research question. The researcher interpreted the observation and interview and also analyzed students' worksheet to find out the problem of the students during the treatment.

\section{RESULTS AND DISCUSSIONS}

Having conducted the research, the researcher found the problems that occurred during the treatment. Based on analysis of students' worksheets it was the students lack of vocabulary, so they can not make a good sentence and it happened before the treatments. The researcher found on the students answer sheets that all of them still use English-Indonesian language, and that was the effect of the students' problem. According Sulasti (2003) the problem that they mostly face are about how to write, what to be written and lack of vocabulary words as well as incompetence in structure. After the researcher gave them the treatments, some of the students made good paragraphs. On the other hand, according to the interview and the observation during the treatment the other problem was some of the students still confused with the use of tenses and dictions, one of the student told the researcher that she was still confuse in the use of past tense and past continuous tense. The researcher did the interview aimed to know the students' problem in mastering writing recount text by using picture series. In this research the researcher use unstructured interview. Paton (2002) described unstructured interviews as a natural extension of participant observation, because they so often occur as a part of ongoing participant observation fieldwork. There was one question that given by the researcher to some students. It could be seen in the dialogue below:

Interviewer: "According to you what is the problem that you faced in your writing recount text after using picture series?"

Student 1 : "if it is from the picture, I rather difficult to decide the plot from one picture to another"

Interviewer: "According to you what is the problem that you faced in your writing recount text after using picture series?"

Student 7 : "it is rather difficult to decide the order of the picture because it is not very clear"

Interviewer: "According to you what is the problem that you faced in your writing recount text after using picture series?"

Student 9 : "deciding the point of view dan grammar structure are rather difficult, for example, if we already use past tense, for the rest of the story we should use the past tense again or not?". 
From the data above, it could be concluded that the problem that faced by the students are they still confuse to use past tense and past continuous tense, determine the plot to make a sequential story and specify the order of the picture to the right order.

Regarding the observation, the researcher found the problem that the students faced in mastering writing skill through picture series were: a. students had lack of vocabulary, so the students cannot make a good sentence; $b$. students felt confuse to arrange the paragraphs and use the tenses; c. students used English-Indonesian language in their piece of writing; d. students felt confuse to use the right word (diction) to in their story. From the data of the observation, the researcher concluded that the students' problem in mastering writing skill through picture series were appropriate with the theory, they were lack of vocabulary, difficult to arrange the paragraph into the proper paragraph and confuse in using the tenses. Hence, it shown in the point $\mathrm{a}, \mathrm{b}, \mathrm{d}$ are the problem in mastering writing skill, and the researcher omitted or reduced point $\mathrm{c}$ because it is not the problem in mastering the writing skill, but it is the impact of the problem in mastering the writing skill trough picture series.

The third is analyzing students' worksheets. The researcher found that some of the students still used English-Indonesian language. In addition, it was found that the problems that the students made in their writing recount text worksheets are classified into four aspect of writing, namely organization, content, grammar, and vocabulary. The problem happened in the organization is the orientation analysis of students' works in writing recount text was still less relevant. Furthermore, the students still tell some events in reorientation. Next, concerning the content, the students' worksheet showed that the student has difficulty to formulate main idea and develop supporting idea. It is still very difficult to students to create an effective paragraph. The students writing still was on average level.

Next, regarding the grammar, The problem in this case was related to the use of to be (was/were), auxiliary verbs, regular, irregular verbs etc. The following examples of past tense problem are the ones in bold typed taken from some text, for instance:

1. We were not happy and we cannot took the picture. (T)

2. We are very happy (ET)

3. I help the farmers to planted and harvested the garlic.(MRA)

4. I and my friends following a competition of footsal. (IN)

All sentence above, the students failed to recognize the use of auxiliary in their sentences. For example, in the first sentence, they should use 'could' after subject 'we' because it should have use the form of $\mathrm{S}+$ aux $+\mathrm{V} 1+$ object. The second sentence, the students should use 'was' after subject 'We' because the students talk about past experience. The students should use form $\mathrm{S}+$ was/were + Adjective. The last sentence, the students should use 'helped' after subject 'I', and they should use 'plant' and 'harvest' after to infinitive. The students should use form S + V2 + Object + to + V1

Finally regarding the vocabulary, the result found in students' worksheet is some vocabulary were misused. The following examples of misused of vocabulary are the ones in bold typed taken form some text, for instance:

1. Holiday Yesterday, I and my family had holiday to Ambal beach. (DD)

2. Time I still sit in bench class, ... (LR) 
The sentences above showed that students still have difficulties to choose appropriate vocabulary. They just change Indonesian word into English. The students are still not familiar with common phrase in English. So, the correct word and phrase should be:

1. Last holiday my family and I had holiday to Ambal beach.

2. When I was still junior high school, ...

\section{CONCLUSION AND SUGGESTION}

The problems found during the treatment and after the researcher did the interview and analyzing the students' worksheets and observation sheet, it was found that the students lack of vocabulary, so they cannot make a good sentence. Furthermore, based on the observation sheet, the other problem was some of the students still confused with the use of tenses and diction, one of the students told the researcher that she was still confuse in the use of past tense and past continuous tense, and did not use the right diction. Based on the interview by the researcher and some of the students, they still confuse to determine the first and the next picture that given by the researcher randomly. The researcher found on the students answer sheets that all of them still use English-Indonesian language, and that was the effect of the students' problem.

The researcher found the obstacles during the research were; it was rather difficult to teach the students by using full English while the treatment and it was also difficult to control and manage the class in order to make them pay attention to the researcher and to the material, and sometimes gave them some instruction and explanation using English made them confused. The researcher hopes to the English teacher and also further researcher to find the solution, solve the problem that faced by the researcher and do better that the researcher did. Based on the problem found, the further researcher is also suggested to conduct a research in applying the best treatment of using picture series or another best technique to solve the problem that occurred in students' writing.

\section{REFERENCES:}

Alfian. (2019). The use of picture series in improving students' speaking ability at the second grade of SMP 2 Bae Kudus. Script. Kudus.

Byrne, D. (1988). Teaching writing skills. Londom: Longman

Cahyono, B.Y. (2009). Techniques in teaching EFL writing. Jakarta: State University of Malang Press.

Harmer, J. (2004). How to teach writing. New York: Longman.

Jacobs, H., Zinkgraf, S., Wormuth,D., Hartfiel, V., \& Hughey, J. (1981). Testing ESL composition: A practical approach. Rowley, MA: New Bury House.

Kharma, Nayef. (1987). Arab Students' Problem with English Relative Clause. ERIC Joural.

Richards, J. C. \& Renandya, W. A. (2002). Methodology in language teaching. New York: Cambridge University Press.

Setiyadi, Ag. Bambang. (2018). Metode penelitian untuk pengajaran bahasa asing (pendekatan kuantitatif dan kualitatif ). Yogyakarta: Graha Ilmu

Sulasti, Yenny. (2003). The structure of the paragraphs written. Universitas Bengkulu.

Tarigan, G. H. (2008). Menulis sebagai suatu keterampilan berbahasa. Bandung: Angkasa

Westwood, Peter. (2008). What teachers need to know about reading and writing difficulties. Australia: ACER Press. 
Wright, Andrew. (1992). Pictures for language learning. Cambridge: Cambridge University Press. 